\title{
Enhanced Combustion Low NOx Pulverized Coal Burner
}

Preliminary Economic Analysis of the Enhanced Low NOx Pulverized Coal Burner

TOPICAL REPORT

Reporting Period Start Date - October 1, 2004 Reporting Period End Date - September 29, 2006

Submitted By

ALSTOM Power Inc. Power Plant Laboratories 2000 Day Hill Road Windsor, CT 06095

(860) 688-1911

Principal Authors:

Ray Chamberland

Aku Raino

David Towle

Prepared For

NETL AAD Document Control Bldg. 921

US Department of Energy

National Energy Technology Laboratory

P.O. Box 10940

Pittsburgh, Pennsylvania 15236-0940

(Cooperative Agreement No. DE-FC26-04NT42300)

Topical Report Submittal Date: September 29, 2006

Performance Period: October 1, 2004 - December 31, 2006 


\section{DISCLAIMER}

This report was prepared as an account of work sponsored by an agency of the United Sates Government. Neither the United States Government nor any agency thereof, nor any of their employees makes any warranty, express or implied, or assumes any legal liability or responsibility for the accuracy, completeness, or usefulness of any information, apparatus, product, or process disclosed, or represents that its use would not infringe privately owned rights. Reference herein to any specific commercial product, process, or service by trade name, trademark, manufacturer, or otherwise does not necessarily constitute or imply its endorsement, recommendation, or favoring by the United States Government or any agency thereof. The views and opinions of authors expressed herein do not necessarily state or reflect those of the United States Government or any agency thereof. 


\section{ACKNOWLEDGMENTS}

The financial support of this project is provided by the U.S. Department of Energy / National Energy Technology Laboratory under Cooperative Agreement No. DE-FC26-04NT42300 with cofunding from ALSTOM Power Inc.

The authors acknowledge Doug Hart and Glen Jukkola of ALSTOM Power Inc. for their contributions of the work presented herein. 


\section{PUBLIC ABSTRACT}

For more than two decades, ALSTOM Power Inc. (ALSTOM) has developed a range of low cost, in-furnace technologies for NOx emissions control for the domestic U.S. pulverized coal fired boiler market. This includes ALSTOM's internally developed TFS $2000^{\mathrm{TM}}$ firing system, and various enhancements to it developed in concert with the U.S. Department of Energy (DOE). As of 2004, more than 200 units representing approximately 75,000 MWe of domestic coal fired capacity have been retrofit with ALSTOM low NOx technology. Best of class emissions range from $0.18 \mathrm{lb} / \mathrm{MMBtu}$ for bituminous coals to $0.10 \mathrm{lb} / \mathrm{MMBtu}$ for subbituminous coals, with typical levels at $0.24 \mathrm{lb} / \mathrm{MMBtu}$ and $0.13 \mathrm{lb} / \mathrm{MMBtu}$, respectively.

Despite these gains, NOx emissions limits in the U.S. continue to ratchet down for new and existing (retrofit) boiler equipment. If enacted, proposed Clear Skies legislation will, by 2008, require an average, effective, domestic NOx emissions rate of $0.16 \mathrm{lb} / \mathrm{MMBtu}$, which number will be reduced to $0.13 \mathrm{lb} / \mathrm{MMBtu}$ by 2018. Such levels represent a $60 \%$ and $67 \%$ reduction, respectively, from the effective 2000 level of $0.40 \mathrm{lb} / \mathrm{MMBtu}$. Low cost solutions to meet such regulations, and in particular those that can avoid the need for a costly selective catalytic reduction system (SCR), provide a strong incentive to continue to improve low NOx firing system technology to meet current and anticipated NOx control regulations.

In light of these needs, ALSTOM, in cooperation with the DOE, is developing an enhanced combustion, low NOx pulverized coal burner which, when integrated with ALSTOM's state-ofthe-art, globally air staged low NOx firing systems, will provide a means to achieve less than $0.15 \mathrm{lb} / \mathrm{MMBtu}$ NOx at less than $3 / 4$ the cost of an SCR with low to no impact on balance of plant issues when firing a high volatile bituminous coal. Such coals can be more economic to fire than subbituminous or Powder River Basin (PRB) coals, but are more problematic from a NOx control standpoint as existing firing system technologies do not provide a means to meet current or anticipated regulations absent the use of an SCR.

The DOE/ALSTOM program performed large pilot scale combustion testing in ALSTOM's Industrial Scale Burner Facility (ISBF) at its U.S. Power Plant Laboratories facility in Windsor, Connecticut. During this work, the near-field combustion environment was optimized to maximize NOx reduction while minimizing the impact on unburned carbon in ash, slagging and fouling, corrosion, and flame stability / turn-down under globally reducing conditions. Initially, ALSTOM utilized computational fluid dynamic modeling to evaluate a series of burner and/or near field stoichiometry controls in order to screen promising design concepts in advance of the large pilot scale testing. The third and final test, to be executed, will utilize several variants of the best nozzle tip configuration and compare performance with 3 different coals. The fuels to be tested will cover a wide range of coals commonly fired at US utilities. The completion of this work will provide sufficient data to allow ALSTOM to design, construct, and demonstrate a commercial version of an enhanced combustion low NOx pulverized coal burner.

A preliminary cost/performance analysis of the developed enhanced combustion low NOx burner applied to ALSTOM's state-of-the-art TFS $2000^{\mathrm{TM}}$ firing system was performed to show that the burner enhancements is a cost effective means to reduce NOx. 
TABLE OF CONTENTS

\begin{tabular}{|c|c|c|c|c|c|c|}
\hline DISCLAIMER & . & - & . & - & . & . \\
\hline ACKNOWLEDGEMENTS . & - & . & . & . & . & . \\
\hline PUBLIC ABSTRACT & . & - & - & - & - & - \\
\hline EXECUTIVE SUMMARY. . & . & - & - & - & - & - \\
\hline 1. Introduction & - & - & - & - & - & - \\
\hline 2. Initial Economic Analysis a & Results . & - & - & - & - & - \\
\hline 3. Initial Conclusions and Rec & nendations & . & . & . & . & . \\
\hline
\end{tabular}




\section{LIST OF FIGURES}

Figure 1 - NOx Emissions of Three Representative Boilers - Pre- and Post-Modification of

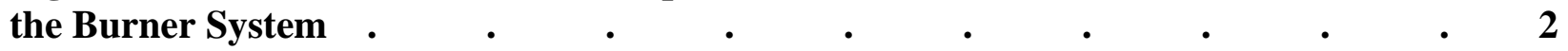
Figure 2 - Simple Payback of Nozzle Tips Modification By NOx Credits $\quad$ • $\quad$ - 3 


\section{EXECUTIVE SUMMARY}

ALSTOM Power Inc., Power Plant Laboratories (ALSTOM-PPL) is currently working to develop a new low NOx coal nozzle tip for tangentially-fired utility boilers. Under this program ALSTOM-PPL is performing 3-weeks of large pilot scale combustion testing in its Industrial Scale Burner Facility (ISBF) to help optimize the near-field combustion environment in order to maximize NOx reduction while minimizing the impact on unburned carbon in ash, slagging and fouling, corrosion, and flame stability / turn-down under globally reducing conditions. ALSTOM is also utilizing computational fluid dynamic modeling to help evaluate and understand the burner performance and to help refine promising nozzle tip concepts. After completion of the testing, a cost / performance analysis of the developed enhanced combustion low NOx burner applied to ALSTOM's state-of-the-art TFS $2000^{\mathrm{TM}}$ firing system in comparison to SCR will be performed to ensure the project objectives are met. The completion of this work will provide sufficient data to allow ALSTOM to design, construct, and demonstrate a commercial version of an enhanced combustion low NOx pulverized coal burner.

Two coal nozzle tips were selected for testing as a baseline of current ALSTOM firing system technology, a standard shear bar / air deflector tip and an LNCFS ${ }^{\text {TM }}$ P2 tip, ALSTOM's current low NOx coal nozzle tip. Four new coal nozzle tip ideas were selected for evaluation in the first week of ISBF testing, completed in November 2005. Two additional coal nozzle concepts were added for the second week of ISBF testing, along with modifications to several of the week 1 tips. The week 2 ISBF testing was completed in March.

Results of the second week showed reductions in NOx emissions of as much as $45 \%$ compared to the baseline coal nozzle tips. This reduction in NOx emissions was achieved with generally lower carbon in the fly ash. Prior to this testing it was not clear that emissions reductions of this magnitude were possible from coal nozzle tip modifications under deeply staged conditions.

A preliminary economic assessment of the enhanced low NOx pulverized coal burner system was conducted based on three utility boilers studied under the DOE/NETL - ALSTOM program titled "Ultra Low NOx Integrated System for NOx Emission Control from Coal-Fired Boiler" under the DOE/NETL Cooperative Agreement No. DE-FC26-00NT40754 (report issued December 30, 2002). An initial economic evaluation was performed on the developed enhanced combustion low NOx burner applied to three tangential-fired over-fired air (OFA) equipped, utility boilers in the U.S.: (1) a 400 MW boiler on the East coast firing an Indonesian subbituminous coal, (2) a 500 MW boiler in the Midwestern U.S. firing a local bituminous coal, and (3) a $330 \mathrm{MW}$ boiler in the Western U.S. firing a sub-bituminous coal from the Power River Basin (PRB). The units selected are representative of a large number of the pulverized coal-fired utility boilers in the U.S. A simple payback analysis shows a payback period of four to eight months for the Eastern unit, two to three months for the Mid West unit, and seven to fourteen months for the Western unit. Consequently, the preliminary economic evaluations show that the burner modification on all three units is a cost effective means to reduce NOx. A detailed economic analysis will be continued (again, based on the 2002 DOE / ALSTOM study) with the results provided in the project final report. 


\section{Introduction}

An initial economic evaluation was performed to evaluate the cost/performance analysis of the developed enhanced combustion low NOx burner. The analysis is based on the DOE/NETL ALSTOM study titled "Ultra Low NOx Integrated System for NOx Emission Control from CoalFired Boiler” under the DOE/NETL Cooperative Agreement No. DE-FC26-00NT40754 (report issued December 30, 2002). In the 2002 report, the various NOx reduction options were evaluated as retrofit options for 3 tangential-fired over-fired air (OFA) equipped, utility boilers in the U.S.: (1) a 400 MW boiler on the East coast firing an Indonesian sub-bituminous coal, (2) a 500 MW boiler in the Midwestern U.S. firing a local bituminous coal, and (3) a 330 MW boiler in the Western U.S. firing a sub-bituminous coal from the Power River Basin (PRB). The units selected are representative of a large number of the pulverized coal-fired utility boilers in the U.S.

A description of the analysis work and the results are summarized herein.

\section{Initial Economic Analysis and Results}

The NOx emissions for the three utility boilers examined in this study are shown in Figure 1. The current NOx emissions from the Eastern unit are based on firing an Indonesian coal, the Midwestern unit current NOx levels are based on representative values reported to the EPA over the last several quarters and the Western unit "current" NOx emission is based on the projected NOx emission level from the proposed low NOx system modification. The post-modification data is based on the preliminary projected NOx emission of the boilers' combustion systems modified with the new nozzle tips developed in this program. Furthermore, note that these NOx emissions are preliminary since no testing has occurred yet on the coals used at the Western and Mid West units. The error bars on the post-modification data indicate the range of NOx emissions possible with the enhanced combustion system developed in this program.

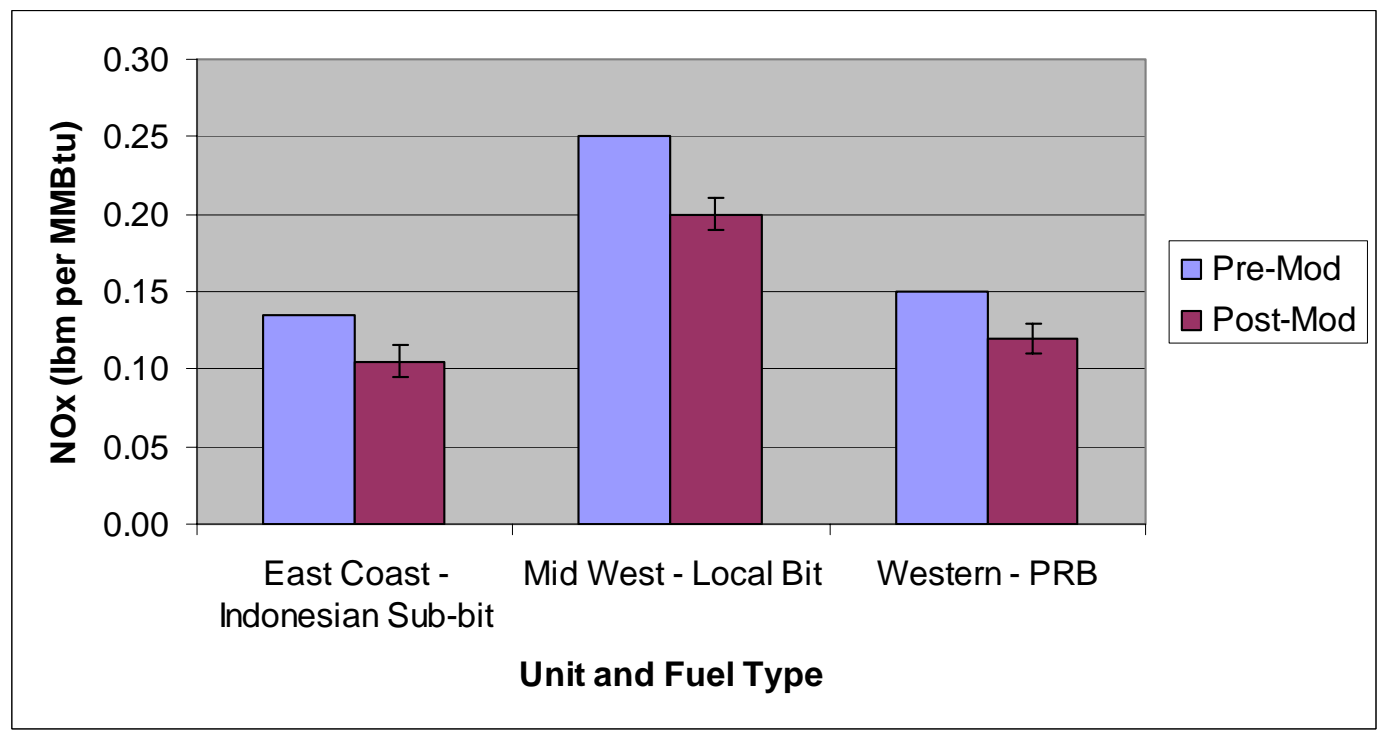

Figure 1 - NOx Emissions of Three Representative Boilers Pre- and Post-Modification of the Burner System 
The units firing the Indonesian coal and Western coal have pre-modification NOx emissions below 0.15 pounds per MMBtu with reduced emissions post-modification. By applying NOx credits to the difference in emissions from pre-modification to post-modification, we can use a simple payback method to indicate the economic feasibility of the burner modification. With a current average NOx credit of $\$ 2,000$ per ton of NOx, the payback times for the three units are shown in Figure 2. The error bars indicate the range of payback times based on the range of NOx emissions possible with the enhanced combustion system developed in this program. For the Western unit, a payback of 7 to 14 months is achievable. For the East Coast unit, a payback of 4 to 8 months is achievable.

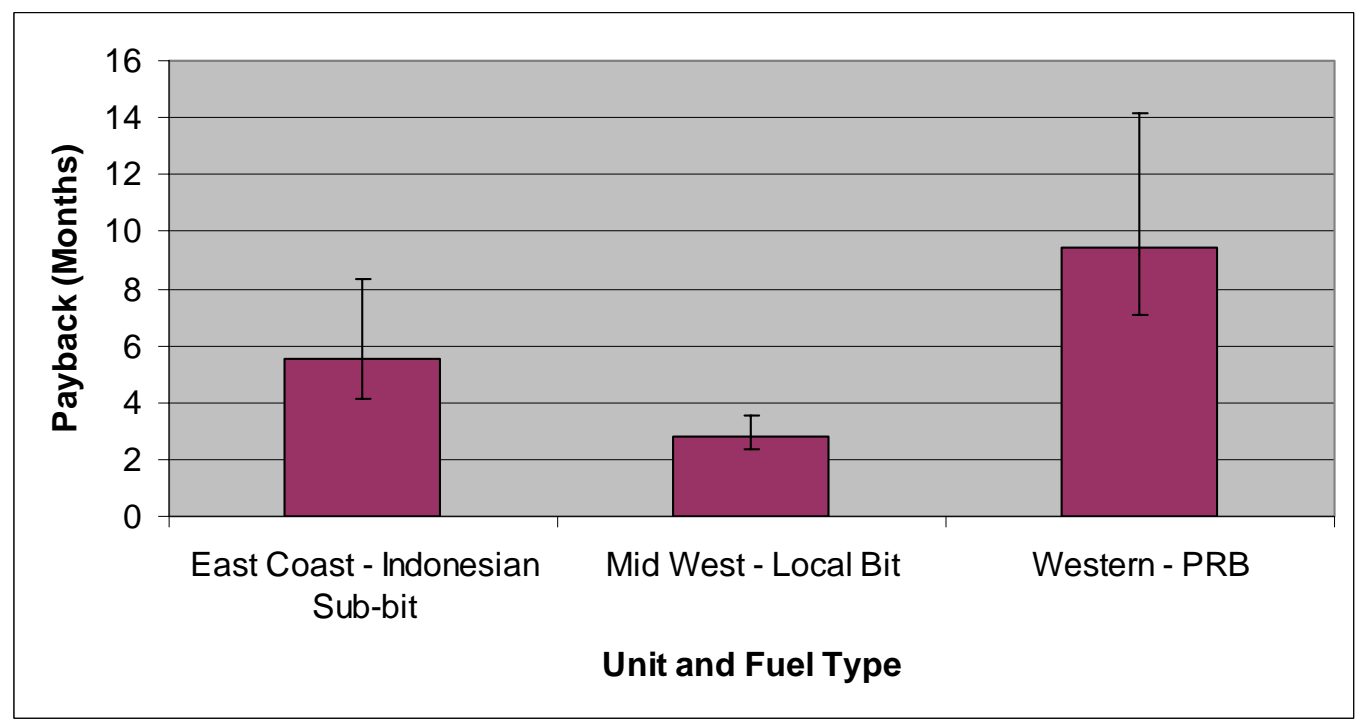

Figure 2 - Simple Payback of Nozzle Tips Modification By NOx Credits

In regards to the Mid West unit, the pre-modification emission is about 0.25 pounds per MMBtu with post-modification emission of about 0.2 pounds per MMBtu. Assuming a 0.15 pounds per MMBtu NOx limit, this unit would need to purchase NOx credits in either scenario; however, fewer credits in the post-modification case are needed. The payback for the burner modification for avoidance of paying for NOx credits between 0.25 and 0.2 pounds per MMBtu is calculated at 2.8 months (again with the $\$ 2,000$ per ton of NOx average credit).

Note that all 3 of these units are similar base modification cases, where there is an existing low NOx system and no current requirement to replace the nozzle tips. In reality there will be a wide range of upgrade scenarios that these new tips will be used for, from replacing worn out tips where the only cost for the additional NOx reduction is the delta between these new tips and OEM replacements, to units where an entire low NOx system system must be installed with the tips. These scenarios will be addressed in the final economic evaluation.

If an SCR is considered for the Mid West unit (assuming $\$ 100$ per $\mathrm{kW}$ capital cost and a maximum of $80 \%$ efficiency) and the avoidance of purchasing NOx credits is considered as the economic driver, then a simple payback calculation shows the payback period of about 84 months for avoiding NOx credits from 0.25 to 0.15 pounds per MMBtu. If the full potential of 
an SCR is used, then the NOx emissions for the unit can drop to 0.05 pounds per MMBtu. In this scenario, the simple payback would become 60 months.

\section{Initial Conclusions and Recommendations}

Preliminary economic evaluations show that the burner modification on all three units is a cost effective means to reduce NOx. A detailed economic analysis will be continued (again, based on the 2002 DOE / ALSTOM study) with the results provided in the project final report. 